ORIGINAL ARTICLE

\title{
ASSOCIATION OF DISEASE HISTORY WITH RHEGMATOGENOUS RETINAL DETACHMENT AMONG PATIENTS IN DEPARTMENT OF OPHTHALMOLOGY AT DR. MOHAMMAD HOESIN ACADEMIC GENERAL HOSPITAL PALEMBANG
}

\author{
Ramzi Amin ${ }^{1}$, Dwi Octaverina Putri ${ }^{2}$, Indri Seta Septadina ${ }^{3 *}$ \\ ${ }^{1}$ Departemen of Ophtalmology, Faculty of Medicine, Universitas Sriwijaya/RSMH, Indonesia \\ ${ }^{2}$ Medical Study Program, Faculty of Medicine, Universitas Sriwijaya, Indonesia \\ ${ }^{3}$ Department of Anatomy, Faculty of Medicine, Universitas Sriwijaya, Indonesia \\ *Corresponding author: indri.andriansyah@gmail.com
}

\begin{abstract}
Retinal detachment is the detachment of neuroretina from pigmented retinal epithelial layer which supplying it. Retinal detachment which is untreated could lead into permanent visual impairment. According to its etiology, retinal detachment can be classified into rhegmatogenous and non-rhegmatogenous, where rhegmatogenous cause is more common that the other. Rhegmatogenous retinal detachment is associated with many previous disease history. Research was to determine the association between previous disease history and rhegmatogenous retinal detachment in the patient in Department of Ophthalmology at Dr. Mohammad Hoesin Academic General Hospital, Palembang. This was an analytical observational study using cross sectional design. Population of study was patients which had been diagnosed as having retinal detachment at the study site. One hundred and fifty-five of 267 patients were taken as study sample by using consecutive sampling technique. Data was obtained from patients' medical records from 1 January 2015 to 31 August 2018. Analysis of association showed the following results: previous cataract surgery $(\mathrm{p}=0,038 ; P R=1,309)$, high degree myopia $(\mathrm{p}=0,014 ; P R=1,400)$ and trauma history $(\mathrm{p}=0,036 ; P R=1,350)$. There were significant associations between previous cataract surgery, high degree myopia and trauma history with rhegmatogenous retinal detachment.
\end{abstract}

Keywords: Previous cataract surgery, myopia, trauma, rhegmatogenous retinal detachment.

\section{INTRODUCTION}

Retinal detachment is the release of the neuroretina (rod cells and cone cells) from the pigmented retinal epithelium layer that supplies it. ${ }^{1}$ In this condition, the pigment epithelial cells are still attached to Bruch's membrane. There is no structural adhesion between neuroretina and pigment epithelium or choroid, so it can be released embryologically. ${ }^{2}$

One of the effects of retinal detachment is that it can cause visual disturbances in the form of decreased visual acuity or visual field that can be persistent if not treated. It is estimated that 
the incidence of retinal detachment is 8.9 cases per 100,000 population. ${ }^{3}$

Retinal detachment is classified into two major types based on the underlying cause, namely the retinal rhegmatogenous ablatio and non-rhegmatogenous retinal detachment. ${ }^{4}$ The cause of rhegmatogenous retinal detachment is the tear of the retina so that the fluid can enter behind the pigment epithelial cells with the retina. The retinal detachment that is not accompanied by retinal tears is a nonrhegmatogenous retinal detachment.

The causes of retinal detachment are retinal thinning and trauma, although trauma is only a supporting factor in the eyes that have been at risk. ${ }^{2}$ Eyes that are at risk for retinal detachment are highdegree eyes with myopia, degeneration of the retina, hereditary vitreoretinopathy, previous intraocular surgery, and ocular inflammation and/or inflammation. ${ }^{5}$

The severity of the impact that can be caused by the rhegmatogenous retinal detachment indicates the importance of prevention efforts. One of the prevention efforts is to know the incidence and history of the disease associated with the rhegmatogenous retinal detachment. This study will explore the incidence and history of diseases associated with rhegmatogenous retinal detachments that occur in RSUP Dr. Mohammad Hoesin Palembang.

\section{METHODS}

This study was an observational analytic study with cross-sectional study design. This study uses secondary data obtained from medical record data of retinal obliteration patients at the Eye Department of RSUP Dr. Mohammad Hoesin Palembang in the period January 2015 to August 2018. The sampling technique in this study used consecutive sampling. The variables studied were a history of cataract surgery, severe degree myopia, trauma, and rhegmatogenous retinal detachment. The following is the flow of research sampling.

The data obtained will be analyzed by univariate and bivariate. Univariate analysis was used to determine the frequency of rhegmatogenous retinal detachment events and to know the frequency distribution pattern of the samples studied. Bivariate analysis using Chi-square test so that it can find out the significance value $(\mathrm{p})$ with a significance level $(\alpha)$ of 0.05 and display the magnitude of Prevalence Ratio (PR), which can interpret the influence of a risk factor on the occurrence of a case.

\section{RESULTS}

The population of this study was all retinal detachment patients who were hospitalized at RSUP Dr. Mohammad Hoesin Palembang from January 1, 2015, to August 31, 2018, totaling 267 data. Sampling using consecutive sampling technique obtained a sample of 155 data patients with retinal detachment who had met the inclusion and exclusion criteria.

\section{Univariate Analysis}

\section{Characteristics of Research Subjects}

In Table 1, the distribution of characteristics of the research subjects is presented. Based on gender, there were 102 (65.8\%) male samples and 53 (34.2\%) female samples. Based on age, there were two groups in this study, namely the age group for more than 50 years and less than 50 years. Of the 155 patients, there were $74(47.7 \%)$ samples aged over 50 years and $81(52.3 \%)$ samples aged under 50 years.

\section{Research Samples Distribution Based on Retinal Ablation Classification}

The classification of retinal detachments in this study was divided into two categories, 
namely rhegmatogenous retinal detachment and non- rhegmatogenous retinal detachment. Samples diagnosed with rhegmatogenous retinal detachment, namely patients experiencing ablation accompanied by tears in the retina. While samples diagnosed with nonrhegmatogenous retinal detachment were patients who experienced ablation without a tear in the retina.

Table 1. Subject Characteristics ( $N=155)$

\begin{tabular}{|c|c|c|}
\hline $\begin{array}{c}\text { Subject } \\
\text { Characteristics }\end{array}$ & $\begin{array}{l}\text { Total } \\
\text { (n) }\end{array}$ & $\begin{array}{c}\text { Percentages } \\
(\%)\end{array}$ \\
\hline \multicolumn{3}{|l|}{ Gender } \\
\hline Male & 102 & 65,8 \\
\hline Female & 53 & 34,2 \\
\hline Total & 155 & 100 \\
\hline \multicolumn{3}{|l|}{ Age } \\
\hline$<10$ years & 1 & 0,6 \\
\hline 10-19 years & 12 & 7,7 \\
\hline 20-39 years & 30 & 19,4 \\
\hline $40-59$ years & 80 & 51,6 \\
\hline$>60$ years & 32 & 20,7 \\
\hline Total & 155 & 100 \\
\hline \multicolumn{3}{|c|}{ Retinal ablation classification } \\
\hline $\begin{array}{l}\text { Retinal ablation } \\
\text { rhegmatogenous }\end{array}$ & 100 & 64,5 \\
\hline $\begin{array}{l}\text { Retinal ablation } \\
\text { non- } \\
\text { rhegmatogenous }\end{array}$ & 55 & 35,5 \\
\hline Total & 155 & 100 \\
\hline \multicolumn{3}{|l|}{$\begin{array}{l}\text { History of Cataract } \\
\text { surgery }\end{array}$} \\
\hline Present & 78 & 50,3 \\
\hline Not present & 77 & 49,7 \\
\hline Total & 155 & 100 \\
\hline \multicolumn{3}{|c|}{ Severe Grade Myopia } \\
\hline Yes & 39 & 25,2 \\
\hline No & 116 & 74,8 \\
\hline Total & 155 & 100 \\
\hline \multicolumn{3}{|l|}{ History of Trauma } \\
\hline Present & 36 & 23,2 \\
\hline Not present & 119 & 76,8 \\
\hline Total & 155 & 100 \\
\hline
\end{tabular}

Based on Table 1, it can be seen from 155 research subjects that there were $100 \quad(64.5 \%)$ samples with rhegmatogenous type and 55 (35.5\%) samples with non-rhegmatogenous type.

\section{Research Samples Distribution Based on Retinal Ablation Classification}

The classification of retinal detachments in this study was divided into two categories, namely rhegmatogenous retinal detachment and non- rhegmatogenous retinal detachment. Samples diagnosed with rhegmatogenous retinal detachment, namely patients experiencing ablation accompanied by tears in the retina. While samples diagnosed with nonrhegmatogenous retinal detachment were patients who experienced ablation without a tear in the retina.

Based on Table 1, it can be seen from 155 research subjects that there were $100 \quad(64.5 \%) \quad$ samples with rhegmatogenous type and 55 (35.5\%) samples with non-rhegmatogenous type.

\section{Frequency Distribution of Retinal Ablation Based on History of Previous Cataract Surgery}

In this study, the previous history of cataract surgery was divided into two categories: history and no history. Samples that had a history of cataract surgery were previously included in the history category, while samples that did not have a history of cataract surgery were included in the no history category.

Based on Table 1, it can be seen that of the 155 retinal detachment patients at RSUP Dr. Mohammad Hoesin Palembang present with history by $78 \quad(50.3 \%)$ samples and no history present as many as $77(49.7 \%)$ samples. 
Frequency Distribution of Retinal Ablation Based on Severe Degree Myopia

Severe myopia in this study is divided into two categories, namely yes and no. The risky sample is a retinal detachment patient accompanied by myopia with minus above 6 diopters. Whereas the nonrisk samples are retinal detachment patients accompanied by myopia with minus 6 diopters or without myopia.

Based on Table 1, it can be seen that of the 155 study subjects, there were 39 $(25.2 \%)$ with severe degrees of myopia, and $116(74.8 \%)$ samples without severe myopia.

Frequency Distribution of Retinal Ablation Based on Trauma History

In this study, the trauma history category was divided into two, namely history and no history. Samples that have experienced trauma to the eye are included in the category of history, while samples that have never experienced trauma to the eye are included in the no history category.

Based on Table 1, it can be seen that from 155 subjects, there were 36 (23.2\%) samples present with trauma history, and $119(76.8 \%)$ present with no history.

Bivariate Analysis

Relationship History of Cataract Surgery with Rhegmatogenous Retinal Ablation

The obtained p-value of 0.038 based on the results of the analysis using the Chisquare test. $\mathrm{H} 0$ is accepted, it can be concluded that there is a significant relationship between the history of cataract surgery and retinal rhegmatogenous ablation in patients at the Eye Department of RSUP Dr. Mohammad Hoesin Palembang. The relationship between the history of previous cataract surgery and rhegmatogenous retinal detachment can be seen in Table 2.

Buletin Farmatera

Fakultas Kedokteran (FK)

Universitas Muhammadiyah Sumatera Utara (UMSU)

http://jurnal.umsu.ac.id/index.php/buletin_farmatera
The Relationship of Severe Myopia with Rhegmatogenous Retinal Ablation

This study shows the p-value of 0.014 based on the results of the analysis using the Chi-square test. H0 is accepted, it can be concluded that there is a significant relationship between severe degree myopia and retinal rhegmatogenous ratio in patients at the Eye Department of RSUP Dr. Mohammad Hoesin Palembang. The relationship of the history of previous intraocular surgery with the rhegmatogenous retinal detachment can be seen in Table 3.

Table 2. Relationship between History of Cataract Surgery and Retinal Ablation rhegmatogenous ( $N=155)$

\begin{tabular}{lccccc}
\hline $\begin{array}{l}\text { History of } \\
\text { Cataract } \\
\text { Surgery }\end{array}$ & \multicolumn{2}{c}{$\begin{array}{c}\text { Retinal Ablation } \\
\text { rhegmatogenous }\end{array}$} & \multirow{2}{*}{$\begin{array}{c}\text { Total } \\
\text { (n) }\end{array}$} \\
\cline { 2 - 4 } & \multicolumn{2}{c}{ Yes } & \multicolumn{2}{c}{ No } & \\
\cline { 2 - 4 } & $\mathbf{n}$ & $\mathbf{\%}$ & $\mathbf{n}$ & $\mathbf{\%}$ & \\
\hline Present & 57 & 73,1 & 21 & 26,9 & 78 \\
Not Present & 43 & 55,8 & 34 & 44,2 & 77 \\
\hline Total & 100 & 64,5 & 55 & 35,5 & 155 \\
\hline & \multicolumn{4}{c}{0,038} \\
\hline PR $(95 \% \mathrm{CI})$ & \multicolumn{4}{c}{1,309} \\
\hline
\end{tabular}

Table 3. Relationship between Severe Myopia and Rhegmatogenous Retinal Ablation ( $N=155)$

\begin{tabular}{|c|c|c|c|c|c|}
\hline \multirow{3}{*}{$\begin{array}{l}\text { Severe } \\
\text { Myopia }\end{array}$} & \multicolumn{4}{|c|}{$\begin{array}{l}\text { Ablation Retina } \\
\text { Regmatogenosa }\end{array}$} & \multirow{3}{*}{$\begin{array}{l}\text { Total } \\
\text { (n) }\end{array}$} \\
\hline & \multicolumn{2}{|c|}{ Yes } & \multicolumn{2}{|c|}{ No } & \\
\hline & $\overline{\mathrm{n}}$ & $\%$ & n & $\%$ & \\
\hline Yes: & & & & & \\
\hline$>-6$ & 32 & 82,1 & 7 & 17,9 & 39 \\
\hline Dioptre & & & & & \\
\hline No: & & & & & \\
\hline$<-6$ & 68 & 58,6 & 48 & 41,4 & 116 \\
\hline Dioptre & & & & & \\
\hline Total & 100 & 64,5 & 55 & 35,5 & 155 \\
\hline p-value & 0,0 & & & & \\
\hline $\begin{array}{l}\mathrm{PR} \\
(95 \% \mathrm{CI})\end{array}$ & & & & & \\
\hline
\end{tabular}




\section{Relationship between Traumatic History and Rhegmatogenous Retinal Ablation}

An obtained p-value of 0.036 based on the results of the analysis using the Chi-square test. H0 is accepted, it can be concluded that there is a significant relationship between the history of trauma and the retinal rhegmatogenous ratio in patients at the Eye Department of RSUP Dr. Mohammad Hoesin Palembang. The relationship between the history of previous intraocular surgery and the rhegmatogenous retinal detachment can be seen in Table 4 below:

\begin{tabular}{|c|c|c|c|c|c|}
\hline $\begin{array}{l}\text { Table } 4 \\
\text { Traumatic } \\
\text { Rhegmatog } \\
(\mathrm{N}=155)\end{array}$ & enou & $\begin{array}{r}\text { Relati } \\
\text { IS } \\
\text { I }\end{array}$ & $\begin{array}{l}\text { onsh } \\
\text { istor } \\
\text { Retin }\end{array}$ & & $\begin{array}{r}\text { between } \\
\text { and } \\
\text { Ablation }\end{array}$ \\
\hline \multirow[t]{3}{*}{$\begin{array}{l}\text { Traumatic } \\
\text { history }\end{array}$} & \multicolumn{4}{|c|}{$\begin{array}{l}\text { Rhegmatogenous } \\
\text { Retinal Ablation }\end{array}$} & \multirow[t]{3}{*}{$\begin{array}{l}\text { Total } \\
\text { (n) }\end{array}$} \\
\hline & \multicolumn{2}{|c|}{ Yes } & \multicolumn{2}{|c|}{ No } & \\
\hline & $\mathrm{n}$ & $\%$ & $\mathrm{n}$ & $\%$ & \\
\hline Present & 29 & 80,6 & 7 & 19,4 & 36 \\
\hline Not present & 71 & 59,7 & 48 & 40,3 & 119 \\
\hline Total & 100 & 64,5 & 55 & 35,5 & 155 \\
\hline$p$-value & \multicolumn{4}{|c|}{0,036} & \\
\hline $\mathrm{PR}(95 \% \mathrm{CI})$ & \multicolumn{4}{|c|}{1,350} & \\
\hline
\end{tabular}

\section{DISCUSSION}

From the results of this study obtained a p-value of 0.038 , which means the value of $p<0.05$. This shows that there is a significant relationship between the history of cataract surgery and the rhegmatogenous retinal detachment.

The results of this study are consistent with studies conducted on the North Island of New Zealand which found that there was a significant association between the history of intraocular surgery and the retinal rhegmatogenous ablation. ${ }^{5}$ The majority of the subjects studied in the study had cataract surgery and one-third had complications in the form of rhegmatogenous retinal detachments. However, this is not in accordance with studies conducted in Sweden which showed that a history of previous cataract surgery did not have a large role to support the occurrence of rhegmatogenous retinal ablation. ${ }^{6}$

According to Sheu et al. (2010), a significant relationship between the history of previous cataract surgery and the rhegmatogenous ratio was caused by the acceleration of the vitreous liquefaction process which could risk resulting in retinal detachment..

A study conducted in Japan showed that retinal detachment that occurs after cataract surgery is caused by changes in the vitreous (liquefaction and vitreous that collapse due to the diffusion of hyaluronic acid during surgery), disturbances in the posterior capsule, loss of the vitreous body, and Posterior Vitreous Detachment (PVD). ${ }^{8}$ In the case of rhegmatogenous retinal detachments like this, the symptoms experienced are more severe than in other cases of rhegmatogenous retinal detachments. Total retinal detachment occurs (often involving the macula), multiple small tears, and has a greater risk of experiencing proliferative vitreoretinopathy. ${ }^{9}$

Prevalence ratio 1.309 was obtained which showed that patients with a history of previous cataract surgery had a chance of 1,309 times to experience rhegmatogenous retinal ablation compared to patients who did not have a history of previous cataract surgery.

From the results of this study obtained a p-value of 0.014 , which means the value of $p<0.05$. This shows that there is a significant relationship between the severe degree of myopia and rhegmatogenous retinal ratio.

This result is in accordance with a study conducted in Taiwan which found 
that a person who has a severe degree of myopia is three times more at risk of experiencing rhegmatogenous retinal ablation. ${ }^{10}$ Research in Sweden also supports these results by stating that severe myopia is one of the most influential risk factors for the rhegmatogenous retinal detachment. ${ }^{6}$ While research carried out in Scotland explained that myopia did not affect the incidence of rhegmatogenous retinal detachments. ${ }^{11}$

Rhegmatogenous retinal detachments are often caused by progressive vitreous liquefaction. ${ }^{12}$ The vitreous body located between the lens and the retina consists of $98 \%$ water and $2 \%$ collagen fibers which along with age growth will melt slowly, but this process occurs earlier in eyes with severe degrees of myopia. This is related to the loss of the normal structure of collagen. The melting vitreous body can collapse and cause tears in the retina. The liquid will enter through the tear to the subretinal space. When the liquid enters too much and cannot be accommodated again, the retina will be released. This can cause retinal detachment. ${ }^{13}$

Patients with severe myopia have a greater risk of rhegmatogenous retinal detachment due to the axial lengthening of the eyeball and thinning of the retina. ${ }^{13}$ Axial lengthening of the eyeball causes a greater stretch in vitreoretinal. Vitreoretinal stretches that occur in a long time can cause the retinal layer to escape from the epithelium that supplies it. ${ }^{14}$ Thinning of the retina can increase the risk for tears in the retina, which is one of the initial factors in the formation of the retina. $^{12}$

There was a prevalence ratio of 1,400 which showed that patients with severe degrees of myopia had 1,400 times the chance to experience a rhegmatogenous retinal detachment compared to patients with low-degree myopia or having no myopia at all.

From the results of this study obtained a p-value of 0.036 , which means the value of $p<0.05$. This shows that there is a significant relationship between the history of trauma and the rhegmatogenous retinal detachment.

These results are consistent with the research conducted in New Zealand, which shows that there is a significant relationship between the history of trauma and the rhegmatogenous retinal ratio. ${ }^{5}$ Whereas in the study by Ethiopia which states that the history of trauma has no relationship with the occurrence of rhegmatogenous retinal detachment. ${ }^{15,16}$

Blunt trauma to the eye causes an extension of the orbital horizontal diameter which can be an initiating factor in the pathogenesis of the rhegmatogenous retinal detachment. This happens due to the compression and rapid decompression of the orbit which can result in vitreoretinal traction and produce retinal tears. ${ }^{13}$ This type of retinal tear can be detected early and treated before it develops into a retinal detachment. Other types of eye trauma can also cause retinal detachments such as penetrating trauma and orbital rupture trauma. ${ }^{5}$

Prevalence ratio 1,350 was obtained which showed that patients with a history of trauma had an opportunity of 1,350 times to experience rhegmatogenous retinal ablation compared to patients who did not have a history of trauma.

\section{CONCLUSION}

Based on the results of the study it can be concluded that retinal detachment is more experienced by male patients than women with a ratio of 2: 1 and most patients are in the age range $<50$ years. There were 100 (64.5\%) samples that experienced rhegmatogenous retinal 
detachment from 155 samples of patients with retinal detachments. There was a significant relationship between the history of previous cataract surgery, severe degree of myopia, and a history of trauma with retinal rhegmatogenous ablation in patients at the Eye Department of RSUP Dr. Mohammad Hosein Palembang.

\section{REFERENCE}

1. Paulsen, F., \& Waschke, J. Sobotta Atlas Anatomi Manusia (23rd ed.). Jakarta: EGC. 2014

2. Ilyas, S., \& Yulianti, S. R. Ilmu Penyakit Mata (5th ed.). Jakarta: Badan Penerbit Fakultas Kedokteran Universitas Indonesia. 2017

3. Amin, R. Ablasio Retina Non Regmatogen. Palembang: Fakultas Kedokteran Universitas Sriwijaya. 2013

4. Mathew, R., Sivaprasad, S., Augsburger, J. J., \& Correa, Z. M. Retina. In P. Riordan-Eva \& J. J. Augsburger (Eds.), Vaughan \& Asbury's General Ophthalmology (19th ed.). London: McGraw-Hill Education. 2018

5. Polkinghorne, P. J., \& Craig, J. P. Northern New Zealand Rhegmatogenous Retinal Detachment Study: epidemiology and risk factors. J Clin Exp Ophthalmol, 32. 2004.

6. Farioli A, Hemmingsson T, Kriebel D. Vascular Risk Factors and Rhegmatogenous Retinal Detachment: a Follow-up of a National Cohort of Swedish Men. $\mathrm{Br} J$ Ophthalmol 2016;100. 2015.

7. Sheu SJ, Ger LP, Ho WL. Late Increased Risk of Retinal Detachment after Cataract Extraction. Am J Ophthalmol. Jan;149(1). 2010.

8. Haga A, Kawaji T, Tsutsumi T, Ideta $\mathrm{R}$, Tanihara $\mathrm{H}$. The Incidence of Rhegmatogenous Retinal Detachment in Kumamoto, Japan between 2009. J Clin Exp Ophthalmol; 8: 647. 2017.

9. Hermann MM, Kirchhof B, Fauser S. Temporal Occurrence of Retinal Detachments after Cataract Surgery. Acta Ophthalmol. 2012

10. Chou SC, Yang $\mathrm{CH}$, Lee $\mathrm{CH}$, Yang CM, Ho TC, Huang JS, Lin CP, Chen MS, Shih YF. Characteristics of Primary Rhegmatogenous Retinal Detachment in Taiwan. Eye (21). 2007

11. Saidkasimova S, Mitry D, Singh J, Yorston D, Charteris DG. Retinal Detachment in Scotland is Associated with Affluence. $\mathrm{Br} J$ Ophthalmol;93. 2011. p. 1591-1594.

12. Feltgen, N., \& Walter, P. Rhegmatogenous Retinal Detachment - an Ophthalmologic Emergency. Deutsches Arzteblatt International, 111(1-2),. 2014. p. 222.

13. Ghazi, N. G., \& Green, W. R. Pathology and pathogenesis of retinal detachment. Eye, 16(4). 2002. p. 411421.

14. Neuhann IM, Neuhann TF, Heimann H, Schmickler S, Gerl RH, Foerster MH. Retinal Detachment After Phacoemulsification In High Myopia: Analysis Of 2356 Cases. J Cataract Refract Surg; 34: 2008. p. 1644-1657

15. Solomon B, Teshome C. Factors Predisposing to Rhegmatogenous Retinal Detachment among Ethiopians. Ethiop. J. Health Dev; 25(1). 2011. p. 31-34.

16. Septadina IS. Perubahan Anatomi Bola Mata pada Penderita Diabetes Mellitus. $M K S$; 47(2). 2015. 139-43 